\title{
The Armenian Road to Democracy Dimensions of a Tortuous Process
}

\author{
CEPS Working Document No. 267/ May 2007
}

Maria Raquel Freire and Licínia Simão

\begin{abstract}
This paper looks at the Armenian transition towards democracy, focusing on the internal and external dimensions of the process. I nternally, we consider the decision-making structure, with particular emphasis on the role of leadership, the development of political parties and changes in civil society. Externally, our attention is focused on neighbourly relations and external actors, including international organisations, particularly the European Union (EU), and its specific instrument, the European Neighbourhood Policy (ENP). The paper aims to shed light on the democratisation process in Armenia and the role of the EU in this process, by looking at the relationship between Brussels and Yerevan, at the instruments and strategies in operation, and at the international context in which these changes are taking place.
\end{abstract}

CEPS Working Documents are intended to give an indication of work being conducted within CEPS research programmes and to stimulate reactions from other experts in the field. Unless otherwise indicated, the views expressed are attributable only to the author in a personal capacity and not to any institution with which he is associated.

ISBN-13: 978-92-9079-719-7

Available for free downloading from the CEPS website (http:/ / www.ceps.be)

(c) Freire \& Simão, 2007 


\section{Contents}

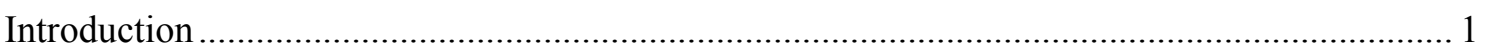

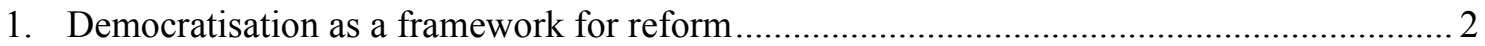

2. Domestic constraints to democracy and catalysts for change.............................................. 3

3. External vectors: Neighbourly relations, external actors and the role of international

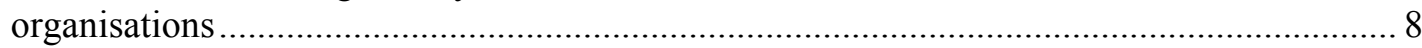

4. Relations between the EU and the South Caucasus.......................................................... 13

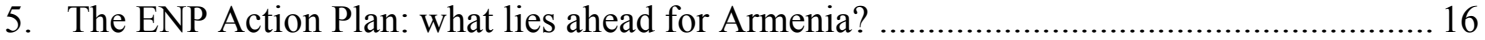

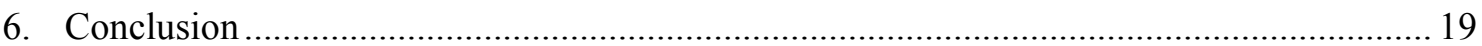

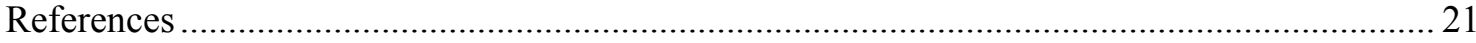




\section{The ARMENian RoAD TO DEMOCRACY DiMENSIONS OF A TORTUOUS PROCESS \\ MARIA RAQUEL FrEIRE AND LICÍNIA SIMÃo*}

\section{Introduction}

The post-communist transition of the former-Soviet republics has been as differentiated a process as the heterogeneity of the former Soviet empire itself. Moving at different paces and in divergent directions, the transition course of these republics has been mixed. Be they Westernoriented, Russia-dependent or other, the processes of democratisation have neither been linear nor irreversible. Situated between Turkey, Azerbaijan, Georgia and Iran in the Caucasus region, Armenian policies have reflected its search for a place in what it considers to be a hostile regional environment. Overcoming domestic constraints and reinventing power structures to accommodate democratic and development needs is, however, a difficult task in a context marked by endogenous and exogenous difficulties.

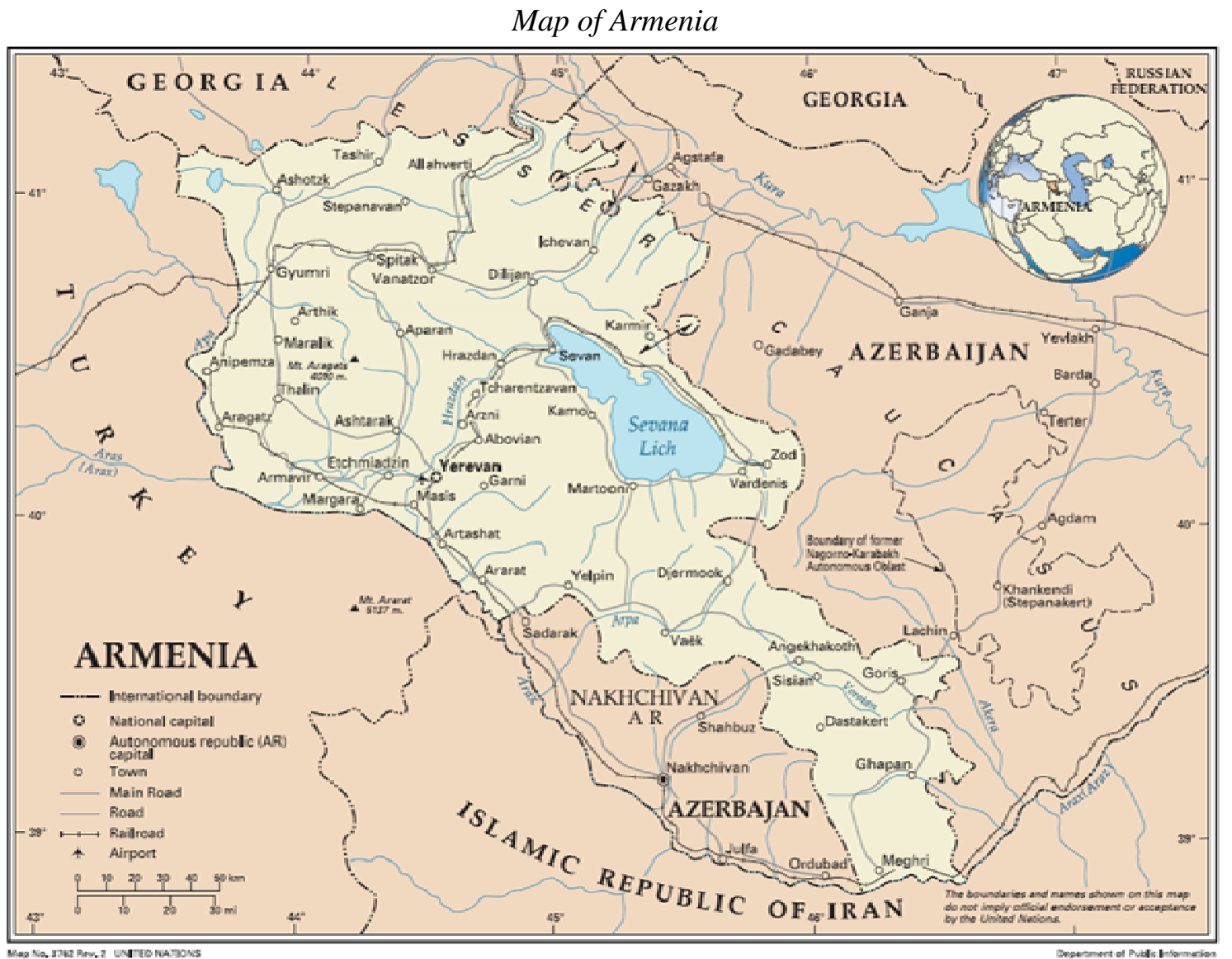

Source: http://www.un.org/Depts/Cartographic/map/profile/armenia.pdf.

\footnotetext{
* Maria Raquel Freire is PhD, International Relations Department, School of Economics - University of Coimbra, Portugal. Licínia Simão is a PhD candidate, University of Coimbra, Portugal, Visiting Research Fellow, CEPS. The authors would like to thank Michael Emerson, Kristi Raik and Bruno Coppieters for their comments and insightful suggestions on previous drafts of this paper.
} 


\section{2 | FREIRE \& SIMÃO}

This paper looks at the Armenian transition towards democracy, focusing on these internal and external dimensions of the process. Internally, we consider the decision-making structures, with particular emphasis on the role of leadership, the development of political parties and changes in civil society. Externally, our attention is focused on neighbourly relations and external actors, including the role of international organisations, particularly the European Union (EU) and its privileged instrument, the European Neighbourhood Policy (ENP). The duration of the transition process and its differentiated phases are also considered of relevance to understanding the choices of the political actors and the outcomes of foreign and domestic policies. This analysis is framed within a conceptualisation of democracy, which includes the holding of multi-party elections (the minimal understanding of democracy according to Schumpeter), ${ }^{1}$ political and institutional accountability, the rule of law and respect for human rights and fundamental freedoms, as well as the development of a strong civil society.

How does the relationship between Brussels and Yerevan affect the transition process? Does the ENP function as a catalyst, or does it generate opposition? And how does the regional context affect this process? By seeking answers to these and other questions, this paper aims to clarify the democratisation process in Armenia, and the role of the EU in this.

\section{Democratisation as a framework for reform}

Armenia has affirmed its ambition to move towards Western liberal democratic and market principles, manifested in concrete steps such as accession to the Council of Europe and the World Trade Organisation (WTO). This demonstrates a desire for change, albeit a desire tempered by contradictions and uncertainty. This commitment has been particularly visible in its efforts towards the development of a market economy, through the pursuit of economic restructuring ${ }^{2}$ and in accepting macro-economic reforms in consultation with international financial institutions. ${ }^{3}$ Results have nevertheless been limited due to a lack of experience regarding democratisation, which is a wholly new concept to a society used to Soviet authoritarian rule for more than 70 years until its independence in 1991.

The holding of free elections has been seen as the first means of assessing transition efforts. However, as in many countries where electoral processes have been held, and despite these having been described as complying with international standards, the practices of government still fall short of democratic. The weak civic participation, the non-existence of multiparty political and civic groupings, and in certain cases, the violation of the fundamental rule of law principles, are all manifestations of a lack of democracy. This results in what has been called "low intensity democracy," where popular mobilisation is discouraged and the governing authorities remain widely discredited. By keeping up an appearance of democracy, the new regimes frequently obstruct endogenous and exogenous processes of democratisation. ${ }^{5}$ This

\footnotetext{
${ }^{1}$ Schumpeter (1952), Capitalism, Socialism and Democracy, London: Allen and Unwyn.

2 Report of the Working Party on the Accession of the Republic of Armenia to the World Trade Organisation, WT/ACC/ARM/23, 26 November 2002 (available at www.wto.org, accessed on 12 March 2007).

3 Most notably the International Monetary Fund, the World Bank and the European Bank for Reconstruction and Development.

${ }^{4}$ See Barry Gils et al. (eds) (1993), Low Intensity Democracy: Political Power in the New World Order, London: Pluto Press.

5 Carl Gershman \& Michael Allen (2006), "New threats to freedom. The assault on Democracy assistance", Journal of Democracy, No. 2(17), April, p. 37.
} 
reality is an example of the dark side of representative democracy, revealing a clear democratic deficit.

An all-encompassing understanding of the concept of democracy is thus fundamental to better assess the reach of the democratisation processes. The expectations associated with these processes, their demands and often deficient implementation, have however led to reversals, demonstrating the difficulties of the post-communist transition - developments that have led critics to question the appropriateness of applying a standard democratisation model. The argument rests on the fact that, in some cases, this procedure leads to the rise of illiberal leaders, and in the extreme might eventually allow civil or inter-state conflict. ${ }^{6}$

An assessment of the Armenian path towards democratisation is closely linked to internal political options and strategic alignments, inscribed in a wider external framing of where Yerevan is located politically, geographically and strategically in a region of divergent interests - the Caucasus. These mixed neighbourly relations are marked by the Nagorno-Karabakh (NK) conflict, rendering the regional setting a complex one. The dispute over the Armenian-populated Azeri enclave of Nagorno-Karabakh developed into a fully armed conflict between Armenia and Azerbaijan in the final days of the Soviet Union. This de facto independent region inside Azerbaijan sought international recognition since the end of the conflict in 1994 and depends on Armenian assistance both in political, economic and military terms. As a result Armenia holds no official diplomatic relations with Turkey and Azerbaijan and has depended on its other neighbours to counterbalance the regional sanctions it suffers. Russia is Armenia's most important partner and good relations with both Georgia and Iran are perceived as an asset in this difficult set-up. In addition, the role of other actors in the area, in particular the EU and the United States, further complicates the political-economic and security dealings of both national and regional policies.

\section{Domestic constraints to democracy and catalysts for change}

Domestic processes of post-communist transition have generally been marked by the simultaneous political challenges of state-building and those associated with transition to a market economy. In the South Caucasus, while the political dimension usually made use of nationalist speeches and was closely linked to the ongoing wars, the economic one was translated into 'shock therapy' measures that allowed the concentration of wealth in the hands of a minority, leading to social polarisation and widespread corruption. ${ }^{7}$ Governmental instability has meant unfinished political, economic and social reforms, leaving the South Caucasus bound by heavy Soviet legacies, such as non-functioning bureaucracies, inefficient economies and weak and still largely undemocratic institutions. ${ }^{8}$ Domestically, one of the major challenges has been, therefore, to 'governmentalise' the executive. As Ashot Khurshusyan points out,

\footnotetext{
${ }^{6}$ See Thomas Carothers (2007), "How Democracies Emerge: The 'sequencing' fallacy", Journal of Democracy, N. 1(18), p. 12. See also Edward Mansfield \& Jack Snyder (1995), "Democratization and War", Foreign Affairs, No. 3(74), pp. 79-97.

${ }^{7}$ Khatchik Derghoukassian (2006), Balance of power, Democracy and Development: Armenia in the South Caucasian regional security complex, Armenian International Policy Research Group, Working Paper No. 06/10, January. See also Norman A. Graham \& Folke Lindahl (eds) (2006), The political economy of transition in Eurasia. Democratization and economic liberalization in a global economy, Michigan: Michigan State University Press.

${ }^{8}$ European Commission, Directorate-General for Economic and Financial Affairs (2006), European Neighbourhood Policy: Economic Review of ENP Countries, Occasional Paper, No. 25, June (available at http://ec.europa.eu/comm/economy finance).
} 


\section{4 | FREIRE \& SIMÃo}

"professional policy making and effective policy management is essential to a successful development of the country", 9 more so in a global context of rapid international and regional integration. In this context, opportunities for development risk being squandered by allowing an elite-driven process to hinder democratisation; a very common feature of regimes in transition.

Armenia has endured a long and painful history of national survival that is still today reflected in social and state dynamics. Its national security strategy reveals a basic need of the state for survival, perceiving itself as an isolated country in a hostile environment, and resorting to external assistance as a way of strengthening its position. ${ }^{10}$ Either against the Ottoman Empire, or the Islamic forces in Iran and Azerbaijan, the Armenian identity was forged amidst nationalist, militarist and religious shields which the NK conflict only ended up reinforcing. As Georgi Derluguian points out, "[f]or the Armenians, the question of Karabagh encapsulated all their historical sorrows and became the symbolic substitute for the much larger trauma of the 1915 genocide and the loss of historical Armenian lands that remained under Turkey's control."11

Amidst such fears, the democratisation of domestic politics where opposing and dissident voices can be heard, has been limited. In addition, a growing militarisation of the Armenian state has been accepted as a "natural and not particularly dangerous" trend, although at some point it raises the question of how far the military has become an agent of regime security rather than national security. ${ }^{12}$ The Armenian diaspora also emerges, at times, as a blocking force, with its images of a militarist and victorious state that largely distort the domestic realities. In this setting, inputs and frameworks for democratisation have been few, and largely undermined by national security issues pushing for hard rhetoric. This rationale for national security is deeply rooted in the Nagorno-Karabakh conflict and in its implications, with the implicit feeling of isolation which prevents Armenia from grasping the political and economic opportunities presented by the international and regional contexts.

The powerful Armenian elites have found support in two important sources, the NagornoKarabakh conflict, which bolsters nationalist feelings and the diaspora, which is an important source of revenues and international pressure. A joint Armenian and Azeri publication on the NK conflict points out that the

Karabakh conflict became a factor in the (early or late) formation of the new national elites claiming political power in Azerbaijan and Armenia and even in the NK. [...] The leaders [in both countries] have forever become hostages to the nationalist slogan and sentiments,

\footnotetext{
9 Ashot Khurshusyan (2003), "Decision Making Process in Armenia legislature" (available at www.policy.hu/khurshud/Final_paper.doc).

${ }^{10}$ Armenia adopted a new Security Strategy on 8 February 2007, the first since independence, stating the country's threats and challenges and the priorities to confront them. The document builds on the concept of complementarity and underlines the importance of democracy and good governance to sustainable development as the basis of reforms. See www.mil.am for the original document in Armenian. See also "Armenian Security Strategy approved" (2007), 8 February (available at www.armeniadiaspora.com, accessed on 9 February 2007).

${ }^{11}$ Georgi Derluguian (2003), Bourdieu's secret admirer in the Caucasus. A world-system biography, Chicago: The University of Chicago Press, p. 189.

12 Richard Giragosian (2006b), Repositioning Armenian Security and Foreign Policy within a region at risk, Armenian International Policy Research Group, Working Paper No. 06/07, March.
} 
and not only because of necessity but also preceding from the fact that continuation of the conflict assured personal power. ${ }^{13}$

Moreover, the war over Nagorno-Karabakh also constrained the foreign policy choices of the Armenian elites since internal legitimacy (including the Diaspora) was directly connected to maintaining support to Karabakh authorities, eliminating any possibility of rapprochement with Turkey, or of diminishing dependence on Russia. ${ }^{14}$ An attempt to define an Armenian national security concept by President Ter-Petrosyan's Armenian Pan-National Movement (APNM) in the first years of independence, followed on the nationalist tradition developed in the final years of the Soviet Union, calling into question a vision of aggressive Pan-Turkism and underlining the benefits of normalising relations with Turkey. ${ }^{15}$ This was a particularly sensitive issue for the diaspora, particularly those who left the motherland to move away from the convulsions that marked the end of the Ottoman Empire and to whom the claim of genocide recognition by Ottoman Turkey is crucial in the national identification processes. The nationalist, conservative and communist parties also perceived this to be an option that could upset Russian policy makers. This eventually proved unsustainable. The domestic perception was deeply linked to the feeling of isolation and threat that had kept the country united, and that would definitely be reflected in the exercise of power.

The constituencies behind Armenian leaders, from Levon Ter-Petrosyan to Robert Kocharian have been connected to NK: the former emerged with the first opposition movement to the Communist Party of Soviet Armenia, after NK asked Moscow to be integrated within Armenia, fully supported by important groups of the diaspora in Moscow. As for Kocharian, he was President of NK and has also been elected President of Armenia with support from the most influential parties in Armenia, namely the Republican Party, the nationalist party Dashnaktsutiun, veteran diaspora-based Ramkavar-Azatakan and Orinats Erkir. ${ }^{16}$ These clanbased political power elites were the ones to seize economic power in independent Armenia, maintaining it from then onwards, and enjoying support from the military. ${ }^{17}$

The new elites in independent Armenia, very much like in most of the post-Soviet countries, have accumulated political and economic power, an accumulation that directly impacts on

\footnotetext{
${ }^{13}$ Ali Abasov \& Haroutiun Khachatrian (2006), Karabakh conflict. Variants of settlement: Concepts and realities, $3^{\text {rd }}$ ed. Baku-Yerevan: Areat/ Noyan Tapan, p. 22.

${ }^{14}$ In the first years after the dismissal of the Soviet Union, the United States pushed for a new role for Turkey in the South Caucasus. Armenia, however, would reject Turkey's pressure to stop supporting the Karabakhs, due to fears that this would de-legitimise the new leadership. See Gevork Ter-Gabrielian \& Ara Nedolian (1997), "Armenia: Crossroads or fault line of civilizations", International Spectator, No. 2 (32), p. 98.

${ }^{15}$ Stephan H. Astourian (2001), "From Ter-Petrosian to Kocharian: Leadership change in Armenia", in Berkeley Program in Soviet and Post-Soviet Studies Working Paper Series, p. 23. It should be noted that the remittances of the diaspora are central to balance the trade deficit and the GDP, as well as for supporting domestic and private consumption levels, having direct impact in Armenia's finances. See Leila Alieva (2000), "Reshaping Eurasia: Foreign policy strategies and leadership assets in post-Soviet South Caucasus", Berkeley Program in Soviet and Post-Soviet Studies Working Paper Series, p. 15 and European Commission (2005), staff working paper, Country Report on Armenia.

${ }^{16}$ Ara Tadevosian (2002), "Kocharian Confident of Second Term”, Caucasus Reporting Service, No. 159, 12 December (available at www.ipwr.net, accessed on 19 January 2007).

${ }^{17}$ Liana Minasian (1999), "The role of the army in Armenia's politics", Caucasus Reporting Service, No. 5, 4 November (available at www.ipwr.net, accessed on 19 January 2007). See also ICG (2004), "Armenia: Internal instability ahead", Europe Report, No. 158, 18 October, on the most powerful clanbased political elites in Armenia.
} 
decision-making, hampering any moves that might jeopardise acquired rights, including the process of liberal democratic transition. As with political accountability and representation, the implementation of a market economy has to be accompanied by the necessary checks and balances to assure procedural transparency working under a legitimate legal framework, which has not been in place. Aware of these fundamental shortcomings, those connected to political power have been exploiting these limitations as an opportunity for the reinforcement of their own power and influence. Nevertheless, this concentration of economic power in the inner circles connected to President Kocharian has been denounced, and in response to domestic and external pressures the government has devised an anti-corruption strategy, ${ }^{18}$ which can be seen, partly at least, as a strategy to keep up an appearance of democracy. Implementation is still largely dependent on government-controlled bodies, and thus subject to further interference.

Reform of the judiciary in this context becomes a priority to break cycles of dependence and patronage and help root democratic processes. Complaints have been on the rise in Armenia regarding the power of oligarchic groups, harassment and unfair competition in political and economic terms, and increasing governmental pressure on supposedly independent media and reporting. ${ }^{19}$ The context of political violence adds an element of fragility to the rooting of democracy. There was a serious incident in 1999, when gunmen entered the Parliament building, shooting Prime-Minister Vezgen Sarkisian and other politicians, including former presidential candidate Karen Demirchian. ${ }^{20}$ The recent attempt to shoot the Mayor of Yerevan is another example of an event incompatible with the goal of consolidating democracy. It is even more compromising that events such as these were never explained in public nor judged in court, indicating that the rule of law is not above political and economic power. A perception of impunity for such 'criminal politics' prevails, particularly in the higher economic and political sectors; a tendency that threatens to undermine state authority and legitimacy. ${ }^{21}$ Furthermore, the abusive use of force by the state authorities after the 2003 Presidential elections, when protesters demonstrating in the streets of Yerevan to denounce the ballot as rigged faced forced dispersion by the army, can also be seen as an attempt at the legitimisation of violent practices.

The interconnections between an independent judiciary and the development of a democratic state are acknowledged. In 2004, a survey conducted in Armenia, revealed that only $12 \%$ of Armenians participating considered that the judiciary was not influenced by political power. ${ }^{22} \mathrm{~A}$ realisation that the very basic foundations of a democratic state in Armenia are still very tenuous and an acknowledgement that "people need to think democratically before acting

\footnotetext{
${ }^{18}$ For more information see Transparency International Armenia (www.transparency.org).

${ }^{19}$ David Petrosian (2001), “Armenian media law sparks protest", Caucasus Reporting Service, No. 66, 19 January (available at www.ipwr.net). Human Rights Watch (2007), World Report 2007. Events of 2006, p. 350 (available at www.hrw.org). Gegham Vardanian (2006), "Armenia: Climate of Self-Censorship", Caucasus Reporting Service, No. 369, 7 December (available at www.ipwr.net, all accessed on 19 January 2007).

${ }^{20}$ For an assessment of the political linkages and implications of this episode see Mikael Danialian (1999), "A disaster for democracy just waiting to happen", Caucasus Reporting Service, 29 October (available at www.iwpr.net, accessed on 19 January 2007).

${ }^{21}$ Richard Giragosian (2006a), "Democracy building blocks: Judicial reform and the rule of law", Armenianow.com, No. 47 (217), 15 December (available at www.armenianow.com, accessed on 5 January 2007).

22 IFES Survey (2004), "Citizens' Awareness and Participation in Armenia", p. 13 (available at www.ifes.org). See also Babken V. Babajanian (2005), "Civic participation in post-Soviet Armenia", Central Asian Survey, No. 24 (3), September, p. 267.
} 
democratically". ${ }^{23}$ This is closely connected to the profound change in social perceptions and habits, and with the idea of the development of a democratic culture being rooted in a vibrant civil society. This has been mostly perceived by foreign actors as complying with the Western model of civic organisation and participation. However, the post-communist reality inherited by Armenia, like in most of the former Soviet-area countries, was that of a social network based on private and kinship connections, a so-called 'economy of favours' - [...] used by people to gain access to institutional resources, obtain goods and services, secure their civil rights and influence decision-making". ${ }^{24}$ It is essentially these features that marked the relationship between the new independent states and their populations.

This type of social organisation reflects the popular perception of the state and the distance between formal institutions and social dynamics. Since social exchanges concentrated on community needs they were never contextualised in the broader framework of state development, such as civil society organisations or political parties. The links between governmental structures and society were therefore undermined..$^{25}$ But despite the disconnection between state structures and society, the nationalist mobilisations in Armenia that followed the revolutionary period between 1988 and 1991 marked a gradual rapprochement between society and the political leaders. The excitement of a new national project, however, failed to deliver democratic results as the legacies of the Soviet period and the difficult strategic environment of the region led to the development of a presidential regime, with extensive power over the Executive and the Parliament, in a political system marked by appeasement and intrigues. ${ }^{26}$

It might be argued, though, that the presence of a large Armenian diaspora in Russia and in Western countries meant that, in the early years of post-communist independence, Armenia "had to maintain its adherence to the global trends of democratisation and openness, a very difficult task, given the internal political crisis affecting the governability of society." 27 This task was also crucial to the maintenance of regional equilibrium in a context of conflict. However, the final ruling years of Ter-Petrosyan were already marked by authoritarian trends, with democratic compliance revealing rather more rhetoric than substantial content. ${ }^{28}$ During Ter-Petrosyan's rule, Armenia developed the pattern of authoritarianism and political pressure that still marks the regime today. ${ }^{29}$

According to the Office for Democratic Institutions and Human Rights (ODHIR), Armenia has registered an improvement in its electoral procedures from 1996 onwards, mostly on account of better access to information and positive synergies from the presence of international monitors. Overall, however, Armenia missed the opportunity to make elections a barometer of its commitment to democracy. ${ }^{30}$ Several problems in electoral processes have repeatedly been reported, including unbalanced media coverage and inadequate use of public funds; the presence

\footnotetext{
${ }^{23}$ Interview with Armen Liloyan, Head of the European Union Division, Ministry of Foreign Affairs of Armenia, Yerevan, 10 May 2006.

${ }^{24}$ Alena Lebedeva (1998), Russia's economy of favours, Cambridge: Cambridge University Press, cited in Babken V. Babajanian (2005), op. cit., p. 267.

${ }^{25}$ Babajanian, op. cit., p. 267.

${ }^{26}$ Leila Alieva (2000), op. cit., p. 12.

${ }^{27}$ Gevork Ter-Gabrielian \& Ara Nedolian (1997), op. cit., p. 113.

28 Ibid.

${ }^{29}$ Stephan H. Astourian (2001), op. cit., p. 43.

30 Sabine Freizer (2005), “Armenia's emptying democracy”, 30 November (available at www.crisisgroup.org, accessed on 19 January 2007).
} 
of government officials and unauthorised personnel at the polling stations; manipulation of the vote of the military; dismissal of a large number of complaints without investigation; technical and organisational shortcomings connected to the constitution of electoral commissions and accuracy in the voters' lists. ${ }^{31}$ In general these problems have led to a decline in public trust in democratic processes, consequently lowering the number of voters and weakening the minimum requirements of a functioning democracy. ${ }^{32}$

In spite of all these difficulties, Armenia has nevertheless been showing signs of growing democratic awareness and making concrete efforts towards a democratisation process. These have, nevertheless, been pursued mainly through the framing of reforms promoted by external actors on the basis of the balance between positive and negative conditionality. Before the 2005 constitutional referendum, the Armenian National Assembly consulted with the Council of Europe Venice Commission on the drafting of the proposal. Major issues under revision related to the appointment of an Ombudsperson, guarantees of independence and plurality of the media, independence of the judiciary, separation of powers and local self-government - all understood as irreplaceable steps towards meeting European standards. ${ }^{33}$ In its report, the Council of Europe's Commission addressed the urgent need to assure implementation of its proposals, with the Parliamentary Assembly of the Council of Europe assuming the task of monitoring Armenia's reforming efforts. In December 2006, an extensive report on these developments was released, aiming already at the next parliamentary and presidential elections in 2007 and 2008 respectively. ${ }^{34}$ These changes, together with the reforms promoted by external actors like the EU and the US, are expected to push Armenia closer to democratic standards of civic participation. Moreover, the recent adoption of the ENP Action Plan, with measures envisaged regarding democratisation, ${ }^{35}$ might help promote beneficial changes in the political and social landscape of Armenia.

\section{External vectors: Neighbourly relations, external actors and the role of international organisations}

Parallel to this difficult internal course, post-Soviet Armenia has been facing several challenges in the definition and consolidation of an independent foreign policy that serves the country's interests. The main priorities of the first independent government, led by President Levon TerPetrosyan, included the normalisation of neighbourly relations, with special emphasis on the resolution of the Nagorno-Karabakh conflict with Azerbaijan. The Karabakh conflict, the consequent trade embargo imposed by Turkey in 1993 and the difficulties associated with the post-independence process have left Armenian society and state structure in too frail a condition to undertake reforms. Hard negotiations over the Karabakh conflict led to the President's resignation and new elections in 1998 brought to power the former NK President and then

31 See http://www.osce.org/documents/odihr/1999/05/1216 en.pdf; http://www.osce.org/documents/ odihr/1998/04/1214_en.pdf; http://www.osce.org/documents/odihr/1996/09/1207_en.pdf.

${ }^{32}$ IFES Survey (2004), op. cit.

${ }^{33}$ Venice Commission (2005), "Opinion on constitutional reform in the republic of Armenia", adopted at $64^{\text {th }}$ Plenary Session, Venice, 21-22 October, (available at http://www.venice.coe.int/, accessed on 14 November 2006).

${ }^{34}$ PACE's Monitoring Committee (2006), "Honoring of obligations and commitments by Armenia", Draft Resolution adopted at Paris meeting, 13 December (available at http://assembly.coe.int/, accessed on 16 December 2006).

35 EU/Armenia ENP Action Plan (available at http://ec.europa.eu/world/enp/pdf/action_plans/ armenia enp ap final en.pdf, accessed on 18 January 2007). 
acting Prime-Minister Robert Kocharian. The main foreign policy lines were maintained, and the integration of Armenia into the international community was underlined by the new government as a strategic goal, ${ }^{36}$ opening up a new opportunity for Armenia to break out of its isolation. Adding to this objective, after September $11^{\text {th }}$, 2001 Armenia formulated the concept of 'complementarity' as a formula to accommodate links to Russia, regional interests and the new proximity policy to Euro-Atlantic structures.

Patterns of enmity and rivalry have dominated the potential space for regional cooperation. Each of the South Caucasus states has a different understanding of its neighbours. ${ }^{37}$ Armenia has no diplomatic relations with neighbouring Azerbaijan due to the outbreak of war in NK, and a constant animosity marks official speeches and public opinion, strongly influencing national politics. Relations with Georgia are not easy, but have a functional character: given the NK conflict and the Turkish embargo, Yerevan has depended on Georgia for land connection with Russia, Armenia's major trade partner and energy supplier. Other issues of concern in bilateral relations with Georgia relate to the Javakheti region in southern Georgia and the Armenian minority living there, as well as to the development of regional economic and energy projects, such as the Baku-Tbilisi-Ceyhan pipeline, the railroad linking Turkey to Azerbaijan via Georgia or the Transcaspian pipeline, all bypassing Armenian territory. What level of solidarity Yerevan is expecting from Tbilisi is not clear, but it is obvious that the main beneficiary from Armenia's situation is Georgia. ${ }^{38}$ Armenia therefore regards the development of strategic relations between Georgia and Azerbaijan with caution and has looked for assurances from Tbilisi that new dividing lines will not be drawn in the southern Caucasus. ${ }^{39}$

Two other crucial players in the South Caucasus are of course Turkey and Iran. After the fall of the Soviet Union, both tried to reassert power in the region by drawing on ethnic and religious factors. As Turkish-Azeri relations developed on a basis of ethnic solidarity, mainly directed against Armenia, Iran became a crucial partner in maintaining the regional balance of power. But Tehran's situation is also complicated, suffering sanctions from the US for a long time and currently sanctioned over its nuclear programme, under a United Nations Security Council resolution. Iran's early strategy towards the South Caucasus was defined by three main aspects: development of strong economic ties; an attempt to take on the role of mediator in the NK conflict, and so avoid it from spreading to its own multi-ethnic society; and cooperation with Russia on defence, strategic and economic issues, mainly to counter Western influence. ${ }^{40}$ In this perspective, relations with Azerbaijan are important to Iran due to a vast Azeri population living in the north of the country, while Armenia is also an important partner with whom Iran enjoys amicable political relations, and has gradually come to support fully, looking to maintain regional balance. Uncertainty about a possible US strike on Iran is causing concern in the South

36 Tiffany G. Petros (2003), Evolution of Armenia's Foreign Policy, Armenian International Policy Research Group, Working Paper No. 03/13, pp. 3-4.

${ }^{37}$ Khatchik Derghoukassian (2006), op. cit.

38 Interviews with senior Armenian Officials, Yerevan, May 2006. Main arguments were related to opportunities missed by Yerevan that ultimately benefited Georgia, such as the development of the BTC through Georgia, when one of the shortest and cheapest routes would have been through Armenia. The same applies to the railroad connecting Baku to Kars, in Turkey. Another argument is that Tbilisi has been chosen as the host city of many international organisations, due to the lack of normalised relations in the region.

39 "Oskanian and Bezhuashvili discuss regional issues" (2007), Armenia Diaspora, 16 January (available at www.armeniadiaspora.com, accessed on 18 January 2007).

40 Aghasi Harutyunyan (2006), Neighborhood relations between the EU and Armenia, Centre for EU enlargement Studies, Central European University, Budapest, June. 
Caucasus. A recent survey in the region points to the drastic consequences for Iran's neighbours if war erupts, further destabilising the region. ${ }^{41}$ The enforcement of sanctions against Iran might impact on Armenia, deepening its isolation in terms of trade, transport and energy. The inauguration of a gas pipeline linking Armenia to Iran serves the national strategy of energy diversification, diminishing dependence on Russian energy coming through Georgia. However, not only did Russian Gazprom move to buy its way into a monopoly position in the Armenian natural gas distribution network, to control Iranian gas entering the country, ${ }^{42}$ but current UN sanctions on Iran further complicates Armenian calculations, constituting a source of concern. ${ }^{43}$

Russia's hold on the South Caucasus is, at this point, reduced to Armenia. Relations with Georgia have reached one of the lowest points in history, particularly after the 'Rose Revolution', and even Azerbaijan, a moderate ally of Moscow has started to show signs of growing independence. ${ }^{44}$ Using energy as leverage this winter, Baku has resisted Moscow's attempt to raise prices over gas, and supported Georgia in doing the same. This has come as a hard blow for Russia's attempt to constrain Georgia into dependence and to destabilise President Saakashvili's pro-western government, as well as to keep an important ally in Baku. President Robert Kocharian and Russian President Vladimir Putin have met frequently and there seems to be a consolidation of the relationship between the two countries. ${ }^{45}$ As Russian financial and economic interests grow in Armenia, the authoritarian tendencies in Moscow are also reproduced in Yerevan, demonstrating how Russia aspires to represent an alternative model to the West in the region. The US has made it clear to the Armenian authorities that closer ties with Washington will be conditional upon a free and fair electoral process, and together with the $\mathrm{EU}$, Washington is using this momentum to push for compromises in NK, supporting high level talks between the two sides. ${ }^{46}$ However, Russia is a central player in the area, with leverage over the NK conflict. It is also part of the Minsk Group, under the OSCE auspices, and responsible for mediation of the conflict, together with the US and France. Russian interests towards the conflict have been described as "maintaining stability and peace in the region", though not necessarily meaning the resolution of the conflict. ${ }^{47}$

In addition, Russia is central to Armenian security, since Yerevan is part of the CIS, and part of the Collective Security Treaty. This has allowed for substantial transfers of military equipment to Armenia, namely from the closure of the Russian military bases in Georgia, and for the

\footnotetext{
41 "Iran: Neighbours worried about possible war", Radio Free Europe/Radio Liberty, 1 March 2007 (available at www.rferl.org, assessed on 2 March 2007).

42 "More Details of Russian-Armenian Gas Deal Released" (2006), Armenian Diaspora, 1 November (available at www.armeniadiaspora.com, accessed on 8 November 2006).

${ }^{43}$ Interview with Paruyr Hovhannisyan, Counsellor at the Armenian Embassy to the European Union, Brussels, March 2007.

${ }^{44}$ Alexandros Petersen \& Taleh Ziyadov (2007), "Azerbaijan and Georgia: Playing Russian roulette with Moscow”, Central Asia - Caucasus Analyst, 10 January (available at www.cacianalyst.org, accessed on 12 January 2007).

${ }^{45}$ President Kocharian held an official visit to Moscow in October 2006, and has been in Russia again twice in early January 2007. See "Putin, Kocharian to Hold More Talks" (2007), Armenia Diaspora, 18 January (available at www.armeniadiaspora.com, accessed on 19 January 2007).

46 "EU hopes for more progress on Karabakh" (2006), Armenia Diaspora, 18 December; "U.S. aid to Armenia linked with clean polls" (2006), Armenia Diaspora, 12 December (available at www.armeniadiaspora.com, accessed on 16 December 2006).

${ }^{47}$ Interview with Maria Babayan, Russian Affairs Department, Ministry of Foreign Affairs of Armenia, Yerevan, 10 May 2006.
} 
maintenance of Russian military at the Armenian-Turkish and Armenian-Iranian borders. Moves that, according to the Armenian authorities, do not represent any relevant change to the existing military balance in the area. In fact, there is a very careful handling of this issue by the authorities in Yerevan that underline the non-threatening character of these moves as a way of minimising any negative effects that might arise. ${ }^{48}$

Besides political-security issues, a new and growing area of Russian influence in Armenia is in the economy. As has happened in most of the former Soviet countries, Russia is using its energy power and growing financial capacity to reassert its influence. Russian capital has been invested in Armenian telecommunications, banking system and electricity networks; ${ }^{49}$ it holds a monopoly position in the gas distribution network, and in order to prevent doubling of gas prices coming from Russia, Armenia has granted Gazprom a share in its largest thermal power plant. ${ }^{50}$ These moves have repeatedly been denounced by opposition leaders as an attempt by the "authorities [to] try to preserve their illegitimate power by selling out the nation's economic facilities." "51

It seems, therefore, that the inputs for democratic consolidation coming from the wider regional context around Armenia are very weak. Conflict has impoverished societies and weakened states, making democratic reforms a second-line goal, and there are no strong democracies to push the South Caucasus countries irreversibly towards a democratic option, as was the case in Central and Eastern Europe. The events in Georgia that brought to power a government with large popular support after the 'Rose Revolution' have not been replicated in Armenia. The benefits of maintaining a 'declaratory democracy' have sufficed for Armenia to keep some level of support from and engagement with the West, though it is not clear how valid this strategy might prove to be in the ENP context. Russia, the strongest of the regional actors, can be increasingly seen as a counterweight to the growing democratic conditionality applied by the West, which it understands as clear interference in an area of vital interest for Moscow.

Western influence and conditionality comes mostly through United States' bilateral aid, NATO and the pan-European institutions such as the EU, the Council of Europe and the OSCE. Particularly since September 11, the US has become an important actor in the South Caucasus. The 2002 annually-renewable national security waiver on the prohibition of aid to Azerbaijan allowed for military cooperation to be boosted with Baku and Yerevan on account of fighting terrorism. ${ }^{52}$ This was further reinforced by financial assistance granted to Armenia for a fiveyear period, under the Millennium Challenge Account, against assurances by Foreign Minister Oskanian that "Armenia would address democratisation shortfalls", reported during the 2005 Constitutional referendum. ${ }^{53}$ However, monitoring of the upcoming elections period by international organisations, such as the OSCE, might not be sufficient to guarantee the

\footnotetext{
${ }^{48}$ Ibid.

${ }^{49}$ Vladimir Socor (2006), “Armenia selling more infrastructure, industry to Russia”, Eurasia Daily Monitor, 7 November (available at www.jamestown.org, accessed on 19 January 2007).

50 "Russia steps up economic presence in Armenia" (2006), Armenia Diaspora, 17 November (available at www.armeniadiaspora.com, accessed on 19 January 2007).

${ }^{51}$ Anna Saghabalian (2006), "Opposition blasts recent economic deals with Russia", 7 November (available at www.armenialiberty.org, accessed on 19 January 2007).

${ }^{52}$ The US kept military cooperation with Yerevan restricted while the ban on Azerbaijan was active, in order not to destabilise the regional military balance resulting from the NK conflict.

${ }^{53}$ Congressional Research Service (2006), "Armenia, Azerbaijan, and Georgia: Political developments and implications for US interests", Issue Brief for Congress, 23 February, p 12 (available at www.fpc.state.gov).
} 
fulfilment of international standards of free and fair elections. Internal shortcomings mingle with international efforts, clearly showing the uphill struggle democratisation has been facing in Armenia. Other issues, such as security, trade and investment, have been privileged areas for US assistance, bearing in mind the strategic location of the South Caucasus as a buffer zone between Europe and Middle East extremism, a spearhead for influence in Central Asia, and a route for energy and trade linking Europe to Asia.

Support for military reforms, integration into NATO structures and the funding of energy projects represent significant changes in US foreign policy for the region as a whole and are welcomed by Armenia, conferring an added leverage to US conditionality. Nevertheless, support for the Baku-Tbilisi-Ceyhan pipeline, the most visible outcome of the alignment between the US, Azerbaijan, Georgia and Turkey, was expected to lead to a countervailing union between Russia, Armenia and Iran. ${ }^{54}$ This understanding, however, did not completely follow through. Armenian-Turkish relations improved as a result of the Turkish process of EU membership and due to growing pressure, particularly from business groups to normalise relations and re-open the Turkish-Armenian border. ${ }^{55}$ At the same time, Iran is increasingly under pressure and is therefore becoming an unstable partner for Armenia, at a time when their relations have been quite close. The volatility of the situation is already very high, and the involvement of external players further sets in motion new dynamics which are not easy to follow. It seems the East-West axis is closer, as can be seen in the growing Turkish and Azeri assertiveness in the Kars-Tbilisi-Baku railroad project put forward without US financing. Armenia, through its 'complementarity' foreign policy has been trying to balance its vital interests with Russia, the West and Iran, but this is an unsatisfactory strategy as the gulf between these different actors grows deeper.

In addition, this is a strategy that can also be understood as a way to accommodate conflicting domestic views over Armenian foreign policy priorities. One such view pertains to the soothing of Moscow's fears of its diminished military influence in its own backyard after September 11. NATO enlargement and the new European Neighbourhood Policy envisage extending the EuroAtlantic structures to the South Caucasus and thus bringing these countries further under the influence of the US and the EU. There is a relevant constituency in the Armenian government, very close to Russia, that perceives the national interest as maintaining a balance more favourable to Moscow than to the West. This can be seen in the reluctance of Armenian officials to declare NATO membership as a national strategic objective. Thus, considering the growing Russian economic influence, one could argue that this small circle in the political elite has seen this to be an important opportunity to increase its financial and economic power, and finds in Russia a strong ally capable of assuring political support even under growing charges of illegitimacy. ${ }^{56}$ These trends have been denounced by opposition figures in Armenia that perceive it as contrary to the national interest.

\footnotetext{
${ }^{54}$ Ozden Z. Oktav (2005), "American Policies towards the Caspian sea and the Baku-Tbilisi-Ceyhan pipeline", Perceptions, No. 1(X), Spring, pp. 20-21.

55 Syuzanna Vasilyan (2006), "The policy of regional cooperation in the South Caucasus", Centro Argentino de Estudios Internacionales, pp. 32-33 (available at www.caei.com.ar, assessed on 17 January 2007).

${ }^{56}$ Richard Giragosian (2003), Geopolitics and the formation of foreign policy in the South Caucasus: An examination of Armenia, Azerbaijan, and Georgia, Armenian International Policy Research, p. 8.
} 


\section{Relations between the EU and the South Caucasus}

EU involvement through the ENP was an added factor in pushing for reforms. As Michael Emerson and Gergana Noutcheva have pointed out, "European integration is a distant but conceivable prospect; integration with the US is not". ${ }^{57}$ Identification with Europe through historical ties and a sense of unprecedented opportunity for economic integration, as well as political support from a strong and reliable partner directly involved with Armenia's most problematic neighbours, was central to the decision to enhance relations with the EU. In fact, the extension of the ENP to the countries of the South Caucasus renders the EU a privileged partner for the promotion of regional cooperation. ${ }^{58}$ In addition, Turkey's negotiations for EU accession are seen in Armenia as a possibility for normalisation of relations, with implications at the wider regional level. Therefore, the lack of progress in the enlargement process with Turkey is likely to have negative effects in the rapprochement between Armenia and the EU, and in their relations with Russia. ${ }^{59}$

The inclusion of the South Caucasus countries in the ENP underlines the importance that stabilisation and conflict resolution in the region have for European security in general, as pointed out in the European Security Strategy. ${ }^{60}$ Moving from a framework that marked the first years of relations between the EU and independent CIS countries, stabilisation evolved from development assistance under the TACIS programme, to Partnership and Cooperation Agreements, centred on closer political and economic dialogue, and to the most recent ENP Action Plans, reflecting a willingness to better coordinate efforts and policies towards the region. ${ }^{61}$ This all-encompassing policy is meant to signal the political will inside the EU for a deeper commitment to the South Caucasus, bringing the neighbouring regions of the Union to some level of integration that would replicate, at least partially, the democratisation and liberalisation effects resulting from the enlargement policy. This is not without a great deal of uncertainty. In fact, Armenian representatives acknowledge the difficulty in pursuing the process of democratisation smoothly in the face of harsh conditions both at home and in the neighbourhood. Though the potential is there, it has also not been used to the utmost, both due to inadequacy of external procedures and the non-readiness of domestic structures. ${ }^{62}$

57 Michael Emerson \& Gergana Noutcheva (2004), Europeanisation as a gravity model of democratisation, CEPS Working Document No. 214, CEPS, Brussels, November, p. 17.

${ }^{58}$ Interviews with Armen Liloyan, Head of the European Union Division, Ministry of Foreign Affairs of Armenia, Yerevan, 10 May 2006; Valery Mbrtannian, Director, International Organisations Department, Ministry of Foreign Affairs of Armenia, Yerevan, 10 May 2006; Garik Adamyan, Director of the TACIS National Coordination Unit at the Ministry of Finance and Economy, Yerevan, Armenia, 9 May 2006.

59 "Turkey is the country that pushes us all the time towards Russia. It is an abnormal attitude that the national security of our country is greatly related to Russia", Interview with Karen Bekaryan, Chairman of NGO European Integration, Yerevan, 11 May 2006.

${ }^{60}$ European Security Strategy (2003), “A secure Europe in a better world”, Brussels, 12 December.

${ }^{61}$ Maria Raquel Freire \& Licinia Simão (2006), “Политика EC в отношении республик Закавказья: В поисках общего в неоднозначной ситуации” (“The EU's Neighborhood Policy towards the Southern Caucasus: Searching for Commonalty in a Patchy Scenario"), Comparative Constitutional Review Journal, Vol. 57, No. 4, pp. 136-144 (in Russian); and Yelda Demirag (2004-05), "EU policy towards South Caucasus and Turkey", Perceptions, No. 4 (IX) winter, p. 96.

${ }^{62}$ Interviews with Armen Liloyan, Head of the European Union Division, Ministry of Foreign Affairs of Armenia, Yerevan, 10 May 2006; Garik Adamyan, Director of the TACIS National Coordination Unit at the Ministry of Finance and Economy, Yerevan, Armenia, 9 May 2006. 
Major issues in the enlarged EU neighbourhood are linked first and foremost to the so-called 'frozen conflicts' of Abkhazia, South Ossetia and Nagorno-Karabakh. This situation of permanent conflict has impacted on the way South Caucasian people perceive their societies and political institutions, and is responsible for weak economic performance, both due to mismanagement and corruption, and to the missed opportunities for development. The EU has recognised the damaging effect of the conflicts on stabilisation and democratic and economic development of the area. The appointment of a Special Representative for the South Caucasus (EUSR) in 2003 signalled an intention to play a more significant role in conflict resolution in the region. ${ }^{63}$ It has, however, been received with some scepticism in Yerevan. Formally the EU involvement is understood as increasing, as the broadening of the Special Representative's mandate reveals, but in practice the Armenian authorities understand it as too vague for concrete accomplishments and not adding fundamentally to further advances in the NK conflict. In addition, they regret the fact that there is no EU resident ambassador in Yerevan. ${ }^{64}$ The views expressed by Armenian diplomats in Brussels, more than a year after the new EUSR began his functions are somehow different, revealing a more positive approach to Ambassador Semneby's new competencies and to his support of the Minsk group's activities, according to the wording of his mandate. ${ }^{65}$

International pressure coordinated with other international organisations like the OSCE and the Council of Europe has, nevertheless, evidenced some advances in the NK negotiations, and in developing incentives for democratic reforms. The period leading up to accession to the Council of Europe (1996-2001) is recognised to have been one of the most constructive phases in Armenian-Azeri relations and in the NK conflict resolution efforts. ${ }^{66}$ Armenia has not asked for a change in the Minsk Group format where the EU is not represented. This reveals a perception by Yerevan that keeping an old ally in the negotiations - France - is more useful for its objectives than would be a EU representation that is much harder to lobby. This amounts to a very pragmatic assessment by the Armenian authorities regarding EU involvement: not as relevant as to make a difference pushing for a final resolution of the conflict, but still relevant enough to develop considerable incentives that might change the status quo.

The EU, through the promotion of its core values - the so-called 'transformative power" ${ }^{67}$ - has been welcomed in the South Caucasus. Regional identities have been described as European, ${ }^{68}$ and the strong economic, ethic and political appeal of the Union is the most promising project available for the area since independence. The ENP represents a real, even if limited, possibility to engage with the EU, following the postulates of peace and prosperity. However, diverging

\footnotetext{
${ }^{63}$ Nicu Popescu (2007), "The European Union and the conflicts in the South Caucasus", Caucaz, 8 January (available at www.caucaz.com).

${ }^{64}$ Interview with Armen Liloyan, Head of the European Union Division, Ministry of Foreign Affairs of Armenia, Yerevan, 10 May 2006.

65 Interview with Paruyr Hovhannisyan, Counsellor at the Armenian Embassy to the European Union, Brussels, 21 March 2007.

${ }^{66}$ Georgia was admitted into the Council of Europe in 1999, prior to Armenia and Azerbaijan, which were admitted only in 2001, as a response to the Nagorno-Karabakh dispute. See Tiffany Petros (2003), op. cit., p. 13. See also PACE (2000), “Armenia's application for membership of the Council of Europe", Opinion, No. 221.

67 Peter Semneby, declarations at the EPC conference on "Bringing peace \& stability to the South Caucasus: The role of the EU", Brussels, 1 March 2007.

${ }^{68}$ President Kocharian has stated this European vocation repeatedly since he was re-elected in 2003. “Armenia's foreign relations in 2003", 14 January 2004 (available at www.deutsch-armenischegesellschaft.de/dag/rbkkt-armenia_fp2003.pdf).
} 
views persist among the government and within the opposition. EU involvement was regarded as an opportunity to diversify relations and to engage in economic reforms and regional integration necessary to sustain a weakened economy. Armenia was never a demandeur state in the EU's neighbourhood and it has kept commitments on a shallow basis, hampering effective results of life-quality improvement for Armenian citizens. However, Armenian officials seem to understand the possible drastic effects for Armenia's future of the lack of genuine democratic reforms and, conditionality is then presented not only as 'good', but even 'healthy' for the country, as it tries to prove itself "the most democratic in the South Caucasus." ${ }^{\prime \prime 9}$ Growing democratic conditionality linked to the ENP process and the redesign of EU's financial instruments might develop into an important mechanism for reforms, rewarding those truly committed to democracy. ${ }^{70}$

In addition, the EU is not a strong military actor, with the US and Russian military influence remaining central for regional security. The governments of the region are well aware that the EU cannot replace the role of these actors. Moreover, they also understand the EU as still having to better define its mechanisms for greater involvement in the region, along with its strategic guidelines, in order that it moves on from "declarative rhetoric to more practical action" ${ }^{71}$ This is more so given the fact that the EU is going through a particularly difficult period, enlarged to 27 member states and without a political charter to make it more functional it is becoming more diverse and thus more difficult to manage. Divergent perspectives among the 'old' and the 'new' member states as to the depth of relations with the Eastern neighbours, the relations with Russia and the management of the common neighbourhood, as well as EU involvement in conflict resolution issues, have exposed the weaknesses of a model still running on inter-governmental arrangements. While the ENP as a valued instrument might be capable of maintaining the EU neighbours' interest in reform, this could also prove to be the "litmus test for Europeanisation". ${ }^{72}$ Two fundamental challenges emerge for the ENP: managing the expectations of the neighbourhood and defining the policy's added value vis-à-vis other regional options and other European policies.

The inclusion of the EU into the Caucasian 'great game' must be related to regional perceptions regarding external influence. Each regional state has its own understanding of how it can profit from the involvement of different external actors. For Georgia, the US is the military counterbalance to Russia, since the EU has denied any military involvement in the conflicts and even refused to send police members to monitor the Georgian-Russian border after the OSCE's mission was ended by Russia (the small EU Border Support Team - BST Georgia - launched in September 2006, includes a group of a few field mentors, experts, operationals and administrative staff, in support of the EUSR work in Tbilisi). ${ }^{73}$ Removal of the remaining Russian military bases in Batumi and Akhalkalaki has been agreed, but the replacement of the CIS peacekeeping troops in Abkhazia and South Ossetia by an international contingent, are urgent demands from Tbilisi, while pushing for NATO membership. For Azerbaijan, the

\footnotetext{
${ }^{69}$ Interview with Paruyr Hovhannisyan, Counsellor at the Armenian Embassy to the European Union, Brussels, 21 March 2007.

${ }^{70}$ Michael Emerson, Gergana Noutcheva \& Nicu Popescu (2007), European Neighborhood Policy two years on: Time indeed for an 'ENP Plus', CEPS Policy Brief No. 126, CEPS, Brussels, March (available at www.ceps.eu).

${ }^{71}$ Interview with Armen Liloyan, Head of the European Union Division, Ministry of Foreign Affairs of Armenia, Yerevan, 10 May 2006.

72 Emerson \& Noutcheva (2004), op. cit., p. 9.

${ }^{73}$ Interview with officials from EUSR office, Tbilisi, 30 October 2006.
} 
preferred option is no military presence. Cooperation with NATO after September 11 opened Azeri territory to the US military, but this could change in case of US-led attacks on Iran. As for Armenia, it has drawn on 'complementarity' as an appeaser for growing Russian concern about US military presence in 'its backyard'. NATO exercises, authorisation to US flights to Afghanistan to cross Armenian air space, and participation in Iraq's combat forces have proved to be compatible with the presence of Russian soldiers along the border with Turkey and Iran, despite support for NATO being met with both suspicion and pressure on a domestic level. ${ }^{74}$

If for a while Russia's biggest fear was NATO enlargement to its former area of influence, the 2004 EU enlargement has made it clear to Moscow that the levels of integration proposed by the European model mean a severe limitation to Russian influence. That is to say, that should the South Caucasus countries ever be offered an accession perspective, this would demand a more serious engagement with the methods and legislation coming from Brussels. The idea that in order for cooperation and even integration into the EU to be developed, Russia should adopt European rules and standards, and submit its elites to supranational institutions, clashes with the perception Russia has of itself and its place in the world. ${ }^{75} \mathrm{EU}$ and Russian perceptions of their common security neighbourhood differ: the EU sees it as preventive engagement while Russia understands it as fierce competition. The lack of constructive dialogue between Brussels and Moscow, and the increasingly inflamed rhetoric between Moscow and Washington could impact on the South Caucasus, by placing it on a new fault line. ${ }^{76}$

\section{The ENP Action Plan: What lies ahead for Armenia?}

Armenia's ENP Action Plan is based on a bilateral and differentiated approach, as stated in the ENP strategy paper issued by the Commission. The goal is to guarantee that each state partner has room to advance its own priorities for reform, taking into account geographical location, political and economic situation, relations with the EU and neighbouring countries, as well as perceived interests, needs and capabilities. However, the basis for cooperation is a clear commitment to shared values and regional collaboration. ${ }^{77}$ Major issues addressed run from democracy promotion, rule of law, respect for human rights and fundamental freedoms, social cohesion and sustainable economic development, through economic legislation convergence and improvement of the business climate, to an energy strategy including the decommissioning of the Medzamor nuclear power plant. Conflict resolution in Nagorno-Karabakh and regional cooperation complete the vast set of issues and objectives the EU has established together with Yerevan. ${ }^{78}$ The negotiation process leading to the conclusion of the Action Plan was a time of particular leverage for the EU and it was used to engage the authorities in Baku and Azerbaijan

\footnotetext{
${ }^{74}$ The dismissal of Arthur Bagdasarian from the post of Parliament Speaker came after declarations that Armenia's security should rest on NATO and not on Russia. Interview with MP of the Armenian National Assembly, Brussels, 13 February 2007.

${ }^{75}$ Roy Allison, Margot Light and Stephen White (2006), Putin's Russia and the enlarged Europe, Oxford: Blackwell Publishing, p. 67.

${ }^{76}$ The decision to locate the US anti-missile defence system in Eastern Europe or in the South Caucasus could be understood by Moscow as an unacceptable situation. See Russian Minister of Foreign Affairs, Sergey Lavrov's interview published in the Newspaper Rossiiskaya Gazeta on 21 and 28 February 2007, available:

http://www.mid.ru/brp 4.nsf/e78a48070f128a7b43256999005bcbb3/0c0b970f129c4556c32572920029a89d?OpenDocument.

77 European Commission, Communication on “ENP Strategy Paper”, Brussels, 12 May, COM (2004) 373 final.

${ }^{78}$ EU/Armenia ENP Action Plan.
} 
in some level of dialogue, though still not carrying enough pressure to reach agreement. To the point that this could be perceived as an attempt to foster regional engagement, it was a strategy that provoked much criticism. In fact, it implied inter-state linkage and conditionality in terms of the advancement of negotiations, with the regional approach again revealing its limits. ${ }^{79}$

The negotiation of the Action Plans for the South Caucasus countries was particularly delicate, as the Commission tried to maintain the balance between differentiation and regional cooperation. ${ }^{80}$ A permanent attempt to maintain balance between EU approaches to Armenia and Azerbaijan is still valid today, as the EU insists on opening a fully-fledged delegation in Yerevan only when it might do the same in Baku. The reasons for such an option, besides avoiding further regional instability, are not fully clear. One EU diplomat has put forward a 'civilisational' explanation, underlining that the EU ascribes as much importance to Christian Armenia and Georgia as it does to Muslim Azerbaijan. ${ }^{81}$ This might be true to the extent that the EU does not wish to see a moderate Islamic country antagonised unnecessarily, but it does not explain why the ENP was extended to Azerbaijan and not to other Islamic countries close to the EU such as Iran, for instance. Since the main issue keeping the South Caucasus both linked together and torn apart is the Nagorno-Karabakh conflict, it is more natural for the EU to privilege a regional perspective as a way of bringing all involved actors together and to keep the possibilities for conflict resolution open. The final wording of the Armenian and Azeri ENP Action plans reflects this search for balance. The final Action Plan for Azerbaijan reads as follows:

[T]he European Neighbourhood Policy of the European Union sets ambitious objectives based on mutual commitments of the EU and its Member States and Azerbaijan to common values, including the respect of and support for the sovereignty, territorial integrity and inviolability of internationally recognised borders of each other (...)

referring to conflict resolution as the first priority. ${ }^{82}$ In the Armenian Action Plan, there is no reference to the principle of territorial integrity and the reference to conflict resolution comes as one of the last points. And while reference to the principle of self-determination is added in the Armenian document, it is not included in the Azeri Action Plan. ${ }^{83}$ This is a language game demonstrating an effort at finding an acceptable format to the parties, and an attempt not to interfere with the basic principles agreed at negotiations under the auspices of the OSCE. Clearly the EU does not see itself as having, or wishing to have, a wider role in the NK conflict, at least for the time being.

For those in the neighbourhood, economic benefits could play an important role in mobilising the population and political elites for reform, as seems to be the main idea with the incentives

\footnotetext{
${ }^{79}$ Interview with Armen Liloyan, Head of the European Union Division, Ministry of Foreign Affairs of Armenia, Yerevan, 10 May 2006.

${ }^{80}$ Generally speaking, the capability of the EU to differentiate among the South Caucasus states was limited. This was particularly visible when the EU suspended the official negotiations of the ENP Action Plans with all three South Caucasus countries, due to Azeri flights connecting to northern Cyprus. The EU maintains sanctions on that part of the island and regarded the Azeri attitude as running against EU interests. This was repeatedly denounced by Georgia and Armenia as an unfair measure, not in line with the differentiation principle of the ENP and revealing a preference towards regional formats over individual relations. For more detail on this see Freire \& Simao (2006), op. cit., p. 10.

${ }^{81}$ Interview with EU Official, Tbilisi, 3 May 2006.

${ }^{82}$ EU/Azerbaijan ENP Action Plan (available at http://ec.europa.eu/world/enp/documents en.htm).

${ }^{83}$ EU/Armenia ENP Action Plan (available at http://ec.europa.eu/world/enp/documents en.htm).
} 
for economic integration of ENP countries into the EU Single Market. ${ }^{84}$ However, if corruption and mismanagement of public affairs by elites remain current practice, "vicious circles of resistance to economic and political reforms are created" 85 and the expected benefits will not be visible, considerably diminishing the effectiveness of the integration process.

This is perceived in some sectors of Armenia's political sphere, particularly the opposition parties, as an issue of particular concern. Economic development and integration into world markets is central for Armenia's security as it faces a blockade from Turkey and Azerbaijan, and is becoming increasingly dependent on Russia. ${ }^{86}$ The major issue is how far dissenting voices will be allowed in Armenian political life and the extent to which they will make a difference in the strategic choices of the ruling elites. The evolving democratisation process runs the risk of being jeopardised and even aborted if economic development is not translated into improvement of social conditions, as well as respect for human rights and fundamental freedoms. It is therefore in the EU's best interests to put forward democratic governance, rule of law, human rights and civil society as the centrepieces of the ENP, while supporting political conditionality mechanisms that will make its neighbours comply, acting on the economic appeal the EU represents. These two factors - conditionality and socialisation - become the major drivers for change towards one of the legal principles binding the EU member states, which is the principle of democracy. ${ }^{87}$

Plans ahead for a concrete and effective EU policy in the region and an enhancement of ENP capabilities might include strengthening of political dialogue, both with partner countries and external partners, such as Russia, the US, Turkey and Iran; enhanced economic and political benefits; and external assistance programming linked to conditionality. ${ }^{88} \mathrm{~A}$ fundamental regional dimension is also underlined in the Commission's Communication "On strengthening the European Neighbourhood Policy", mostly through the enhancement of a Black Sea Dimension that became clearer after Bulgaria and Romania accessed the EU. Here the EU should enhance internal coordination of its policies to ensure that ENP states, members and candidates have equivalent possibilities to cooperate, even if under different policies. This is also expected to add leverage to the EU conflict resolution mechanisms. ${ }^{89}$ A particularly worrying trend for Armenia is the development of regional infrastructures like the BTC pipeline and the Kars-Akhalkalaki-Baku railroad, both bypassing Armenian territory, and leaving the country out of what is seen as the revival of the Silk Road. Previous efforts to revive this

${ }^{84}$ ENP Strategy Paper, op. cit. See also External Relations and Neighbourhood Commissioner FerreroWaldner Speech (2006), "EU in the World", Brussels, 3 February.

${ }^{85}$ Emerson \& Noutcheva (2004), op. cit., p. 17.

${ }^{86}$ Richard Giragosian (2005), Toward a new concept of Armenian National Security, Armenian International Policy Research, Working Paper No. 05/07, pp. 10-11.

${ }^{87}$ Michael Emerson, Senem Aydýn, Gergana Noutcheva, Nathalie Tocci, Marius Vahl and Richard Youngs (2005), The Reluctant Debutante: The European Union as Promoter of Democracy in its Neighborhood, CEPS Working Document No. 223, CEPS, Brussels, July, p. 4; Elena Bacarani (2004), "The EU and Democracy Promotion: A Strategy of Democratization in the Framework of Neighborhood", in Fulvio Attinà \& Rosa Rossi (eds), European Neighborhood Policy: Political, economic and social issues, Jean Monnet Centre "Euro Med" p. 41.

${ }^{88}$ International Alert (2006), Peacebuilding in the South Caucasus: What can the EU contribute?, September, p. 35 (www.international-alert.org). See also Emerson, Noutcheva \& Popescu (2007), op. cit.

${ }^{89}$ European Commission communication to the Council and the European Parliament "On strengthening the European Neighbourhood Policy", Brussels, 4 December, COM (2006)726 final. See also Fabrizio Tassinari (2006), A synergy for Black Sea regional cooperation: Guidelines for an EU Initiative, CEPS Policy Brief No. 105, CEPS, Brussels, June. 
connection between Europe and Asia, like the TRACECA and INOGATE programmes, were hampered by lack of dialogue between Baku and Yerevan, with direct implications for Armenian economy and political dealings.

In order for the ENP to develop into a full strategic initiative from which the EU can derive effective power, which in the end means stabilising the countries in its periphery politically, economically and in security terms, the refinement of its policies must be pursued. There seems to be a growing awareness of the potential of the ENP among European officials, along with the unavoidable challenges it must address. Armenia is at the heart of these dynamics: its political transition towards democracy could be jeopardised if conditionality and incentives are not visible; its economic transition and the much praised economic success needs consolidation, so as not to develop into an 'orchid economy ${ }^{90}$ - appealing when looked at from a statistical point of view, but growing in a non-sustainable way. In addition, Armenia is a testing ground for the development of regional cooperation in the southern Caucasus, for conflict resolution, and for the promotion of stable societies capable of driving democracy and modernisation to western standards and thus fully integrated into the European security community.

\section{Conclusion}

This paper has looked at the Armenian road to democracy, understanding it as a tortuous process defined by internal and external dynamics. These two dimensions - internal policies and external factors - have both fostered and hampered the process, which from its very beginning has been defined in terms of the Western liberal democracy model. Understanding democracy in its broader formulation, the Armenian transition course has revealed many difficulties in implementation. Internally, the consolidation of democratic practices at the institutional and decision-making levels has shown limits, in a society used to a strong leadership, and where the power of the local elite in political and economic terms is substantial. These old-style practices render the development of a civil society and the enhancement of rules regarding transparency and accountability very difficult. The recurrent use of violence to suppress dissidence and opposition is a clear example of political and economic allegiances and of the difficulty to establish an independent judiciary. Armenia is thus an incomplete democracy in a regional context where democracy as a model has mostly been the exception. Surrounded by authoritarian regimes in Central Asia, the so-called 'managed democracy' in Russia and the arbitrariness in neighbouring countries, with the possible exception of Georgia, underlines a view that Armenia's efforts at reform, such as the recently adopted Constitutional amendments, should be acknowledged and supported.

It is undeniable that there are many internal obstacles to this process. Nevertheless, Armenia's relations with neighbouring countries and the influence of external actors in the area are central elements that need to be taken into account. The lack of regional cooperation, due to the unresolved Nagorno-Karabakh conflict, and competition for resources and influence in the area, render the geostrategic and political-economic setting highly complex. The lack of diplomatic relations with Azerbaijan and Turkey; difficult relations with Georgia; and cooperative relations with Iran and Russia, despite elements of divergence, render the whole picture bleak. In addition, the EU and the US have also become engaged in the South Caucasus, providing economic, political and even military assistance. From this wide involvement, a complex net of bargaining, concessions and trading of power has emerged. The reconciliation of divergent interests and competing opportunities, along with the challenge of fostering positive cooperative

${ }^{90}$ Dov Lynch's expression used at the EPC Conference on "Bringing peace \& stability to the South Caucasus: The role of the EU", Brussels, 1 March 2007. 
dynamics have proven very hard indeed. In this context, the ENP might be an important catalyst for change both within Armenia and regarding regional cooperation, since the approach in Yerevan is 'benefit driven', through a rational assessment, and not simply a feeling of euphoria. ${ }^{91}$ By enhancing economic cooperation based on a set of agreed principles shared by all ENP countries, it might establish a common platform to translate minimal shared procedures into action, with positive input. Implementing a set of norms and practices according to the EU model, as earlier defined - Europeanisation - establishes common patterns and consists of a simple download of 'ways of doing' that might in the end turn out to be too removed from present Armenian political dynamics.

The scenarios are therefore varied, but an optimistic stance can be taken. Transition should be understood as a long-term process, which takes time to take root but which might assist in stabilising the region. By bringing with it deep reforms and the goal of developing regional cooperation, it might constitute an important confidence-building measure to end the Karabakh conflict, which is a fundamental obstacle to the normalisation of relations in the area. In the process, the role of the elites in power should not be underestimated as a blocking force to reforms that might undermine particular interests. However, offering prospects of new economic opportunities might also constitute an enhancing factor. Russia's influence in the South Caucasus has diminished, particularly in Georgia, but also in Azerbaijan. This has been mostly due to the perception of new options for the region, such as the Euro-Atlantic institutions, understood in Moscow as a counterweight to its influence. Armenian leaders have sought to keep all options open by their policy of complementarity, often linking strategies of personal political survival to the fate of the Armenian nation in a perceived hostile environment. Russia can thus be seen as a maintainer of the status quo, namely regarding conflict resolution issues, though to what extent this plays to its advantage in the long-run is not clear. The US is another relevant player, and its military and energy interests in the Caucasian countries have worked as a solid and credible basis for EU engagement in the region, aligning the EuroAtlantic partnership. However, issues concerning US military intervention in Iraq and the management of the Iranian crisis are still major problems that can affect the strategic engagement of the West in the South Caucasus. In addition, US relations with Russia and with Turkey are also of much relevance regarding the region's balance of power, and for the EU.

In a nutshell, the complexity of interactions, interests and necessary reforms has rendered democratisation a difficult process in Armenia. The commitment to western liberal democracy, though appearing to be highly rhetorical has, nevertheless, been supported by Armenia's participation in international organisations, such as the Council of Europe and OSCE, and in the neighbourhood policy of the EU. Expectations are therefore rising as to the effective results of Armenia's post-communist transition and to the role external players can have in the wider strategic setting in the Caucasus. The Armenian democratisation process looks troubled, with such a complex set of divergent and competing interests, but there are nevertheless identifiable areas for cooperation, which if exploited might open new windows of opportunity for Armenia. The EU, through the ENP, and its particular concretisation in the Action Plan for Armenia, might just be opening one of these windows.

\footnotetext{
${ }^{91}$ Interview with Erik Gulasian, AEPLAC, Yerevan, Armenia, 12 May 2006.
} 


\section{References}

\section{Official documents}

EU/Armenia ENP Action Plan (available at http://ec.europa.eu/world/enp/pdf/action plans/ armenia enp ap final en.pdf).

EU/Armenia ENP Action Plan (available at http://ec.europa.eu/world/enp/documents_en.htm)

European Commission Communication "ENP Strategy Paper”, Brussels, 12 May, COM (2004) 373 final.

European Commission Communication to the Council and the European Parliament, "On strengthening the European Neighbourhood Policy", Brussels, 4 December, $\operatorname{COM}(2006) 726$ final.

European Commission, Directorate-General for Economic and Financial Affairs (2006), European Neighbourhood Policy: Economic Review of ENP Countries, Occasional Paper, No. 25, June (available at http://ec.europa.eu/comm/economyfinance).

European Commission staff working paper, Country Report on Armenia, SEC (2005).

European Security Strategy (2003), "A secure Europe in a better world", Brussels, 12 December.

External Relations and Neighbourhood Commissioner Ferrero-Waldner Speech (2006), "EU in the World", Brussels, 3 February.

OSCE Election Observation Mission - Republic of Armenia (1999), Preliminary Statement, OSCE Office for Democratic Institutions and Human Rights and OSCE Parliamentary Assembly, Yerevan, 31 May (available at http://www.osce.org/documents/odihr/1999/05/ 1216 en.pdf).

OSCE Office for Democratic Institutions and Human Rights (1998), Preliminary Statement by the Election Observation Mission to the Armenian Extraordinary Presidential Election, Second Round, Yerevan, 30 March (available at http://www.osce.org/documents/odihr/ 1998/04/1214 en.pdf).

OSCE Office for Democratic Institutions and Human Rights (1996), Preliminary Statement of the International Observers, Armenian Presidential Elections, Yerevan, 22 September (available at http://www.osce.org/documents/odihr/1996/09/1207_en.pdf).

PACE's Monitoring Committee (2006), "Honouring of obligations and commitments by Armenia".

PACE (2000), "Armenia's application for membership of the Council of Europe", Opinion No. 221.

Draft Resolution adopted at Paris meeting, 13 December (available at http://assembly.coe.int/, accessed on 16 December 2006).

Report of the working party on the accession of the Republic of Armenia to the World Trade Organisation, wt/acc/arm/23, 26 November 2002 (available at www.wto.org, accessed on 12 March 2007).

Transparency International Armenia (www.transparency.org).

Venice Commission (2005), "Opinion on constitutional reform in the republic of Armenia", adopted at $64^{\text {th }}$ Plenary Session, Venice, 21-22 October (available at http://www.venice.coe.int/, accessed on 14 November 2006). 


\section{Papers and books}

Abasov, Ali and Haroutiun Khachatrian (2006), Karabakh conflict. Variants of settlement: concepts and realities, $3^{\text {rd }}$ ed. Baku-Yerevan: Areat/ Noyan Tapan.

Alieva, Leila (2000), "Reshaping Eurasia: foreign policy strategies and leadership assets in post-Soviet South Caucasus", in Berkeley Program in Soviet and Post-Soviet Studies Working Paper Series, Paper 2000_01-alie (available at http://repositories.cdlib.org/ iseees/bps/2000 01-alie).

Allison, Roy, Margot Light and Stephen White (2006), Putin's Russia and the enlarged Europe, Oxford: Blackwell Publishing.

"Armenia's foreign relations in 2003" (2004), 14 January (available at www.deutscharmenische-gesellschaft.de/dag/rbkkt-armenia fp2003.pdf).

"Armenian Security Strategy approved" (2007), Armenia Diaspora, 8 February (available at www.armeniadiaspora.com, accessed on 9 February 2007).

Astourian, Stephan H. (2000), "From Ter-Petrosian to Kocharian: leadership change in Armenia", in Berkeley Program in Soviet and Post-Soviet Studies Working Paper Series, Paper 2000_04-asto (available at http://repositories.cdlib.org/iseees/bps/2000 04-asto).

Babajanian, Babken V. (2005), "Civic participation in post-Soviet Armenia", Central Asian Survey N. 24 (3), September, pp. 209-224.

Bacarani, Elena (2004), "The EU and Democracy Promotion: a Strategy of Democratization in the Framework of Neighborhood", in Fulvio Attinà and Rosa Rossi (eds), European Neighborhood Policy: Political, economic and social issues, Jean Monnet Centre "Euro Med".

Carothers, Thomas (2007), "How Democracies Emerge: the 'sequencing' fallacy", Journal of Democracy, No. 1(18), pp. 12-27.

Congressional Research Service (2006), "Armenia, Azerbaijan, and Georgia: political developments and implications for US interests", Issue Brief for Congress, 23 February (available at www.fpc.state.gov).

Danialian, Mikael (1999), "A disaster for democracy just waiting to happen”, Caucasus Reporting service, 29 October (available at www.iwpr.net, accessed on 19 January 2007).

Demirag, Yelda (2004-05), "EU policy towards South Caucasus and Turkey", Perceptions 4 (IX), winter, pp. 91-106.

Derghoukassian, Khatchik (2006), Balance of power, Democracy and Development: Armenia in the South Caucasian regional security complex, Armenian International Policy Research Group Working Paper No. 06/10, January.

Derluguian, Georgi (2003), Bourdieu's secret admirer in the Caucasus. A world-system biography, Chicago: The University of Chicago Press.

Emerson, Michael and Gergana Noutcheva (2004), Europeanisation as a gravity model of democratisation, CEPS Working Document No. 214, CEPS, Brussels, November.

Emerson, Michael, Senem Aydýn, Gergana Noutcheva, Nathalie Tocci, Marius Vahl and Richard Youngs (2005), The Reluctant Debutante The European Union as Promoter of Democracy in its Neighborhood, CEPS Working Document No. 223, CEPS, Brussels, July.

"EU hopes for more progress on Karabakh" (2006), Armenia Diaspora, 18 December (available at www.armeniadiaspora.com, accessed on 16 December 2006). 
Freire, Maria Raquel and Licinia Simão (2006), "Политика EC в отношении республик Закавказья: в поисках общего в неоднозначной ситуации” (“The EU's Neighborhood Policy towards the Southern Caucasus: Searching for Commonalty in a Patchy Scenario"), Comparative Constitutional Review Journal, No. 4 (57), pp. 136-144 (in Russian).

Freizer, Sabine (2005), “Armenia's emptying democracy, 30 November (available at www.crisisgroup.org, accessed on 19 January 2007).

Gershman, Carl and Michael Allen (2006), "New threats to freedom. The assault on Democracy assistance", Journal of Democracy, No. 4(17), April, pp. 36-51.

Gils, Barry et al. (eds) (1993), Low Intensity Democracy: Political Power in the New World Order, London: Pluto Press.

Giragosian, Richard (2003), Geopolitics and the formation of foreign policy in the South Caucasus: an examination of Armenia, Azerbaijan, and Georgia, Armenian international Policy Research.

Giragosian, Richard (2005), Toward a new concept of Armenian National Security, Armenian International Policy Research Working Paper No. 05/07.

Giragosian, Richard (2006a), "Democracy building blocks: judicial reform and the rule of law", Armenianow.com, Issue No. 47 (217), 15 December (available at www.armenianow.com, accessed on 5 January 2007).

Giragosian, Richard (2006b), Repositioning Armenian Security and Foreign Policy within a region at risk, Armenian International Policy Research Group, Working Paper No. 06/07, March.

Graham, Norman A. and Folke Lindahl (eds) (2006), The political economy of transition in Eurasia. Democratization and economic liberalization in a global economy, Michigan: Michigan State University Press.

Harutyunyan, Aghasi (2006), Neighborhood relations between the EU and Armenia, Centre for EU enlargement Studies, Central European University, Budapest, June.

Human Rights Watch (2007), World Report 2007. Events of 2006, p. 350 (available at www.hrw.org).

ICG (2004), “Armenia: Internal instability ahead", Europe Report, No. 158, 18 October.

IFES Survey (2004), "Citizens' Awareness and Participation in Armenia" (available at www.ifes.org).

International Alert (2006), Peacebuilding in the South Caucasus: what can the EU contribute?, September (www.international-alert.org).

"Iran: neighbours worried about possible war" (2007), Radio Free Europe/Radio Liberty, 1 March (available at www.rferl.org, assessed on 2 March 2007).

Khurshusyan, Ashot (2003), "Decision Making Process in Armenia legislature" (available at www.policy.hu/khurshud/Final_paper.doc).

Lavrov, Sergey, Russian Minister of Foreign Affairs (2007), interview published in the Newspaper Rossiiskaya Gazeta, 21 and 28 February (available at http://www.mid.ru/ brp 4.nsf/e78a48070f128a7b43256999005bcbb3/0c0b970f129c4556c32572920029a89d? OpenDocument).

Lebedeva, Alena (1998), Russia's economy of favours, Cambridge: Cambridge University Press, cited in Babken V. Babajanian (2005), p. 267 
Mansfield, Edward and Jack Snyder (1995), "Democratization and War", Foreign Affairs, No. 3(74), pp. 79-97.

Minasian, Liana (1999), “The role of the army in Armenia's politics", Caucasus Reporting Service, No. 5, 4 November (available at www.ipwr.net, accessed on 19 January 2007).

"More Details of Russian-Armenian Gas Deal Released" (2006), Armenian Diaspora, 1 November (available at www.armeniadiaspora.com, accessed on 8 November 2006).

Oktav, Ozden Z. (2005), "American Policies towards the Caspian sea and the Baku-TbilisiCeyhan pipeline", Perceptions, 1 (X) Spring, pp. 17-35.

"Oskanian and Bezhuashvili discuss regional issues" (2007), Armenia Diaspora, 16 January (available at www.armeniadiaspora.com, accessed on 18 January 2007).

Petersen, Alexandros and Ziyadov, Taleh (2007), "Azerbaijan and Georgia: Playing Russian roulette with Moscow", Central Asia - Caucasus Analyst, 10 January (available at www.cacianalyst.org, accessed on 12 January 2007).

Petros, Tiffany G. (2003), Evolution of Armenia's Foreign Policy, Armenian International Policy Research Group, Working Paper No. 03/13.

Petrosian, David (2001), “Armenian media law sparks protest”, Caucasus Reporting Service, No. 66, 19 January (available at www.ipwr.net, accessed on 19 January 2007).

Popescu, Nicu (2007), "The European Union and the conflicts in the South Caucasus", Caucaz, 8 January (available at www.caucaz.com).

"Putin, Kocharian to hold more talks" (2007), Armenia Diaspora, 18 January (available at www.armeniadiaspora.com, accessed on 19 January 2007).

"Russia steps up economic presence in Armenia" (2006), Armenia Diaspora, 17 November (available at www.armeniadiaspora.com, accessed on 19 January 2007).

Saghabalian, Anna (2006), "Opposition blasts recent economic deals with Russia", 7 November (available at www.armenialiberty.org, accessed on 19 January 2007).

Schumpeter, Joseph (1952), Capitalism, Socialism and Democracy, London: Allen and Unwyn.

Semneby, Peter (2007), declarations at the EPC conference on "Bringing peace \& stability to the South Caucasus: The role of the EU", Brussels, 1 March.

Socor, Vladimir (2006), "Armenia selling more infrastructure, industry to Russia", Eurasia Daily Monitor, 7 November (available at www.jamestown.org, accessed on 19 January 2007).

Tadevosian, Ara (2002), "Kocharian Confident of Second Term", Caucasus Reporting Service, No. 159, 12 December (available at www.ipwr.net, accessed on 19 January 2007).

Tassinari, Fabrizio (2006), A synergy for Black Sea regional cooperation: guidelines for an EU Initiative, CEPS Policy Brief No. 105, CEPS, Brussels, June.

Ter-Gabrielian, Gevork and Ara Nedolian (1997), "Armenia: crossroads or fault line of civilizations", International Spectator 2 (32), pp. 93-116.

"U.S. aid to Armenia linked with clean polls" (2006), Armenia Diaspora, 12 December (available at www.armeniadiaspora.com, accessed on 16 December 2006).

Vardanian, Gegham (2006), "Armenia: Climate of Self-Censorship", Caucasus Reporting Service, No. 369, 7 December (available at www.ipwr.net, accessed on 19 January 2007). 
Vasilyan, Syuzanna (2006), "The policy of regional cooperation in the South Caucasus", Centro Argentino de Estudios Internacionales, pp. (available at www.caei.com.ar, assessed on 17 January 2007).

\section{Interviews}

Garik Adamyan, Director of the TACIS National Coordination Unit at the Ministry of Finance and Economy, Armenia, 9 May 2006.

Armen Liloyan, Head of the European Union Division, Ministry of Foreign Affairs of Armenia, Yerevan, 10 May 2006.

Erik Gulasian, AEPLAC, Yerevan, 12 May 2006.

EU Delegation Official, Tbilisi, 3 May 2006.

Karen Bekaryan, Chairman of NGO European Integration, Yerevan, 11 May 2006.

Maria Babayan, Russian Affairs Department, Ministry of Foreign Affairs of Armenia, Yerevan, 10 May 2006.

MP of the Armenian National Assembly, Brussels, 13 February 2007.

Official from EUSR office, Tbilisi, 30 October 2006.

Paruyr Hovhannisyan, Counsellor at the Armenian Embassy to the European Union, Brussels, 21 March 2007.

Valery Mbrtannian, Director, International Organisations Department, Ministry of Foreign Affairs of Armenia, Yerevan, 10 May 2006. 


\section{About CEPS}

Founded in Brussels in 1983, the Centre for European Policy Studies (CEPS) is among the most experienced and authoritative think tanks operating in the European Union today. CEPS serves as a leading forum for debate on EU affairs, but its most distinguishing feature lies in its strong in-house research capacity, complemented by an extensive network of partner institutes throughout the world.

\section{Goals}

- To carry out state-of-the-art policy research leading to solutions to the challenges facing Europe today.

- To achieve high standards of academic excellence and maintain unqualified independence.

- To provide a forum for discussion among all stakeholders in the European policy process.

- To build collaborative networks of researchers, policy-makers and business representatives across the whole of Europe.

- To disseminate our findings and views through a regular flow of publications and public events.

\section{Assets}

- Complete independence to set its own research priorities and freedom from any outside influence.

- Formation of nine different research networks, comprising research institutes from throughout Europe and beyond, to complement and consolidate CEPS research expertise and to greatly extend its outreach.

- An extensive membership base of some 120 Corporate Members and 130 Institutional Members, which provide expertise and practical experience and act as a sounding board for the utility and feasability of CEPS policy proposals.

\section{CEPS carries out its research via its own in-house} research programmes and through collaborative research networks involving the active participation of other highly reputable institutes and specialists.

\section{Research Programmes}

Economic \& Social Welfare Policies

Energy, Climate Change \& Sustainable Development

EU Neighbourhood, Foreign \& Security Policy

Financial Markets \& Taxation

Justice \& Home Affairs

Politics \& European Institutions

Regulatory Affairs

Trade, Development \& Agricultural Policy

\section{Research Networks/Joint Initiatives}

Changing Landscape of Security \& Liberty (CHALLENGE)

European Capital Markets Institute (ECMI)

European Climate Platform (ECP)

European Credit Research Institute (ECRI)

European Network of Agricultural \& Rural Policy Research Institutes (ENARPRI)

European Network for Better Regulation (ENBR)

European Network of Economic Policy Research Institutes (ENEPRI)

European Policy Institutes Network (EPIN)

European Security Forum (ESF)

CEPS also organises a variety of activities and special events, involving its members and other stakeholders in the European policy debate, national and EU-level policy-makers, academics, corporate executives, NGOs and the media. CEPS' funding is obtained from a variety of sources, including membership fees, project research, foundation grants, conferences fees, publication sales and an annual grant from the European Commission.

E-mail: info@ceps.be

Website: http://www.ceps.be

Bookshop: http://shop.ceps.be 